\title{
TURF IRRIGATION MANAGEMENT BASED ON RECENT TECHNIQUES
}

\author{
$[143$ \\ Nabila A. Mohamed, El-Gindy A.M., El-Bagoury K.F. and Beder O.M. \\ Agric. Eng. Dept., Fac. of Agric., Ain Shams Univ., P.O. Box 68 Hadayek Shoubra 11241, \\ Cairo, Egypt
}

Keywords: Irrigation Scheduling, Central control, Weather station, landscape

\section{ABSTRACT}

Irrigation, water management under climate change conditions plays an important role in rationalizing water uses efficiency in the agricultural development processes specially under aridecosystems conditions. Therefore, the objective of this study was to estimate the irrigation water requirement of savings landscaping areas under different recent techniques. So, this study focused on comparison between fully automatic with central control system (C.C.S) based on weather station and Control unit based on operator experience and background. The experiments were conducted during two years (from January 2014 to December 2015), in the site that located in District 5, New Cairo, Cairo, Egypt.

The results indicated the irrigation scheduling based on weather station data using a central control system (C.C.S) optimized maximize the irrigation water use efficiency and increase the amount of irrigation water saving by about $14 \%, 36 \%, 18 \%$ and $33 \%$ in Autumn, Winter ,spring and summer respectively in year of (2014) and 7\%, 29.7\%, $16 \%, 33 \%$ in Autumn, Winter, spring and summer, respectively in year of (2015) compared with the other irrigation scheduling when based on calculated according to traditional method. In addition, the results revealed that scheduling practices based on weather station data by using central control system could reduce the average of power consumption (about $314 \mathrm{KW}$ ) in year of (2014) and (about $347 \mathrm{KW}$ ) in year of (2015).

Moreover, the results revealed that the cost of water consumption for the central control system based on the data of the meteorological station for the two years 2014 and 2015, the years of study were 106810 L.E./ 2years compared with the other irrigation schedule when calculated according to the operator's experience was 131010 L.E./ 2 years. Where the cost of $36172,13603,23393$ and 33642 L.E./ 2years in the winter, spring, summer, autumn and respectively of the central control system and 39600, 17068, 28820 and 45522 L.E./ 2 years in the winter, spring, summer, autumn respectively of the other system.

\section{INTRODUCTION}

The aim of good management of landscape irrigation is to apply plant materials that require a proper quantity of water right on time. In all areas where water costs are high and the supplies are limited, and there is a high demand for landscapes quality and grass. The irrigation manager must conserve irrigation systems to achieve the highest performance levels and make accurate decisions about when and how much irrigation.(David and Dennis R. Pittenger, 2009) . Water resources are, for most countries, a key factor in their economic and social development (Sebei et al 2004). Hence, according to Naeem and Rai (2005), water shortage requires that new technologies and methods of irrigation be developed that could help in the effective utilization of this precious input.n addition, there is also a need to carry out practices of irrigation water management to achieve high water use efficiency, increase the productivity of water resources (Bharat 2006). In the past 10 years ago ,a number of manufacturers of electrical irrigation controllers companies have developed and promoted these units in an effort to reduce irrigation (Davis and Dukes, 2016). This necessitates innovative and sustainable research, as well as appropriate transfer of technologies (Pereira et al 2002). So the efficient of irrigation management is challenging given the number of factors to be 
considered, including system parameters, irrigation method, crop type, and climate (Dabach et al 2013). It should be noted that, in many regions of the world, climate change will increase the average reference evapotranspiration by $2 \%$ (De Silva et al 2007). Further, there are many irrigation controllers that can calculate the quantity of water used based on climatic situations and ET value (McCready et al 2009). The irrigation controller systems differ in their reliability and accuracy; moreover, all of them based on new electronic sensors, which are qualified of analyzing and collecting data, and making decisions on what the time to start and stop irrigation. These devices transfer decisions to electronic controllers that control the sprinkler system. Also the computer systems and sophisticated software interfaced with valve control and sensor reading capabilities offer the irrigation manager a high degree of control capabilities. This technology, often indicate to as "Central Control Systems", allows precise management of large irrigation systems with considerable labor savings. Central control systems are used for large or expansive facilities, such as large parks, transportation corridors, and golf courses that can incur the expense and have trained staff to manage the system. (David A. Shaw and Dennis R. Pittenger, 2009)

\section{The main objectives of this study were}

- Management of irrigation system (sprayer) for landscape Evapotranspiration daily water requirement by weather station data.
- Evapotranspiration daily water requirement by weather station data.

- Evaluation of irrigation water use efficiency and the amount of irrigation water saving.

\section{MATERIALS AND METHODS}

\section{3-1- Description of the site}

The experiment were carried out in District 5 site, New Cairo, Cairo, Egypt, for two seasons (from January 2014 to December 2015). The total landscaping area of this site is $(60,000$ square meters). The soil of the experimental site is classified as sandy soil and the EC of water about ( 560 $\mathrm{ppm})$. The average of temperature was (35C) in summer and $\left(19^{\circ} \mathrm{C}\right)$ in winter.

\section{3-1-1- Soil properties and irrigation water anal- ysis}

The soil of the experimental site at District 5 site, New Cairo, Cairo, Egypt is classified as sandy soil. The representative soil samples from the different places of the experimental area were taken from the depths $(0-15,15-30$ and $30-45 \mathrm{~cm})$ to determine the physical and chemical properties.

The similar depths of the soil samples were mixed thoroughly and a composite sample were taken for each depth for a different analyses.

Some chemical properties of the soil have been measured as follows: Soil $\mathrm{pH}$ and EC were measured in 1:2.5 (soil: water suspension) in soil paste extract.

Some of the physical and chemical properties of soil is displayed in Tables $\mathbf{1}$ and 2.

Table 1. Some physical properties of soil at the experimental site

\begin{tabular}{|c|c|c|c|c|c|c|c|c|}
\hline \multirow{2}{*}{ Depth (cm) } & \multicolumn{4}{|c|}{ Particle size distribution (\%). } & \multicolumn{2}{c|}{ өS\% on weight bassis } & \multirow{2}{*}{ HC (cm/h) } \\
\cline { 2 - 8 } & $\begin{array}{c}\text { C. } \\
\text { sand }\end{array}$ & $\begin{array}{c}\text { F. } \\
\text { Sand }\end{array}$ & $\begin{array}{c}\text { Silt + } \\
\text { Clay }\end{array}$ & $\begin{array}{c}\text { Texture } \\
\text { Class }\end{array}$ & F.C. & P.W.P. & A.W & H. \\
\hline $0-15$ & 46.72 & 47.78 & 2.47 & Sandy & 12.1 & 4.2 & 7.6 & 23.4 \\
$15-30$ & 53.74 & 37.53 & 3.79 & Sandy & 13.5 & 4.2 & 7.9 & 18.1 \\
$30-45$ & 37.75 & 59.42 & 3.77 & Sandy & 12.5 & 4.3 & 7.9 & 22.1 \\
\hline
\end{tabular}

F.C: Field capacity; PWP: Permanent wilting point (FC and PWP) were determined as percentage (w/w); AW: Available water; HC: Hydraulic conductivity. 
Table 2. Some chemical properties of soil at the experimental site

\begin{tabular}{|c|c|c|c|c|c|c|c|c|c|c|}
\hline Depth & pH & EC & \multicolumn{3}{|c|}{ Soluble Cations meq/L } & \multicolumn{4}{|c|}{ Soluble Anions meq/L } \\
\cline { 5 - 10 }$(\mathbf{c m})$ & $\mathbf{0 1 : 0 2 . 5}$ & $\mathbf{d S} / \mathbf{m}$ & $\mathbf{C a + +}$ & $\mathbf{M g + +}$ & $\mathbf{N a +}$ & $\mathrm{K}+$ & $\mathbf{C O 3}$ & $\mathbf{H C O 3}$ & $\mathbf{S O 4}$ & $\mathbf{C l}$ \\
\hline $0-15$ & 8.5 & 0.37 & 0.45 & 0.41 & 1.06 & 0.24 & 0 & 0.10 & 0.78 & 1.23 \\
$15-30$ & 8.7 & 0.34 & 0.53 & 0.44 & 1.08 & 0.25 & 0 & 0.15 & 0.85 & 1.20 \\
$30-45$ & 8.9 & 0.38 & 0.52 & 0.43 & 1.03 & 0.23 & 0 & 0.13 & 0.83 & 1.25 \\
\hline
\end{tabular}

Table . Some chemical properties of irrigation water at the experimental site.

\begin{tabular}{|c|c|c|c|c|c|c|c|c|c|c|}
\hline \multirow{2}{*}{ pH } & \multirow{2}{*}{$\begin{array}{c}\text { EC } \\
(\mathbf{p p m})\end{array}$} & \multicolumn{4}{|c|}{ Cations, (meq/L) } & \multicolumn{4}{c|}{ Anions, (meq/L) } & \multirow{2}{*}{ SAR } \\
\cline { 3 - 10 } & $\mathbf{C a}^{+2}$ & $\mathbf{M g}^{+2}$ & $\mathbf{N a}^{+}$ & $\mathbf{K}^{+}$ & $\mathbf{C O}_{3}{ }^{-2}$ & $\mathbf{H C O}_{3}^{-}$ & $\mathbf{C l}^{-}$ & $\mathbf{S O}_{4}^{-2}$ & SAR \\
\hline 8.00 & 560 & 2.2 & 0.8 & 1.3 & 0.2 & 0.0 & 1.8 & 1.6 & 1.1 & 1.1 \\
\hline
\end{tabular}

\section{3-2- Spray irrigation system components and experimental layout}

The spray irrigation system consists of PVC for main lines with of $(110 \mathrm{~mm})$ diameter, $63 \mathrm{~mm}$ diameter as sub main lines. The operating pressure of sprayer was 2 bar, discharge is $0.84 \mathrm{~m} 3 / \mathrm{h}$ with $41 \mathrm{~mm} / \mathrm{h}$ precipitation rate. The distance between the sprayers was $4.5 \mathrm{~m}$ between each other. It consisted of centrifugal pump 6"/ 6" with discharge of the pumping unit is $110 \mathrm{~m} 3 \mathrm{~h}^{-1}$ with $59.2 \mathrm{~m}$ head and specific speed $2900 \mathrm{~min}^{-1}$. The electrical motor with power $30 \mathrm{kw}$, voltage 380-415V- $60 \mathrm{~Hz}$. for each pump and about $77 \%$ volumetric efficiency. Moreover, It consisted of three tanks of media filter 48 ", back flow prevention device, pressure gauges and control valves.

3-2-1- The specification and engineering factors of the spryer at different operating pressures

The geometric measurements were at the $\mathrm{Na}$ tional Irrigation Laboratory of Agricultural Engineering Research Institute (AEnRI), Dokki, Giza.

The operating pressure of sprayer is 2 bar, discharge is $0.84 \mathrm{~m} 3 / \mathrm{h}$ with $41 \mathrm{~mm} / \mathrm{h}$ precipitation rate. Arc $360^{\circ} \mathrm{C}$. Some of the specification and engineering factors of the spryer is displayed as following:
Table 3. The specification and engineering factors of the spryer

\begin{tabular}{|l|l|l|l|l|}
\hline${ }^{\star \star}$ Hydraulic performance of spray head \\
\hline Sprinkler & \multicolumn{5}{|c|}{ Spray head } \\
\hline Nozzle & \multicolumn{4}{|c|}{15} \\
\hline (Bar) pressure & 1.5 & 2 & 2.25 & 2.5 \\
(L/m) Flow & 11.4 & 13.2 & 15 & 15.6 \\
(m) Radius & 4.3 & 4.5 & 4.8 & 5.15 \\
\hline
\end{tabular}

\section{3-3- Irrigation Control systems}

3-3-1- Fully Automatic Unit equipped with Central Control System

Central Control is an easy to use for landscape. It consists of computer, Weather Station, Satellitebased System Interfaces, Satellites and Solenoid Valve. The software communicates directly with the weather station to get ET data.

The weather station measures air temperature, wind speed / direction, solar radiation, relative humidity and rainfall.ET values can then be applied to existing programs to adjust run times, based on current weather conditions. 


\section{3-3-2- Control unit}

This system contains of control panel. It is a kind of 12 lines that are programmed on the irrigation time determined by the operator experience which entails the start of the irrigation cycle or disconnect it by sending some signals to run electric valves or to close.

\section{3-4- landscape}

The experiment was planted turf grass (Paspalum Vaginatun) member of Poaceae family.

\section{3-5- Experimental layout}

The total area of the experiment was $243 \mathrm{~m} 2$. It was divided into two plots with dimensions $18 \mathrm{~m} \mathrm{x}$ $4.5 \mathrm{~m}$. Each plot controlled under control valve 1".
The experiment was conducted during two years (from January 2014 to December 2015). The results of the experiment were taken from site in District 5, New Cairo, Cairo, Egypt.

The experimental design was involving two factors ( $\mathrm{T} 1$ and $\mathrm{T} 2$ ) and the study factors were as follows:

two scheduling irrigation treatments

T1. Programming the central control system by data calculated from data taken daily from the automatic weather station in the experimental site.

T2. Programming the control panel by operator experience.

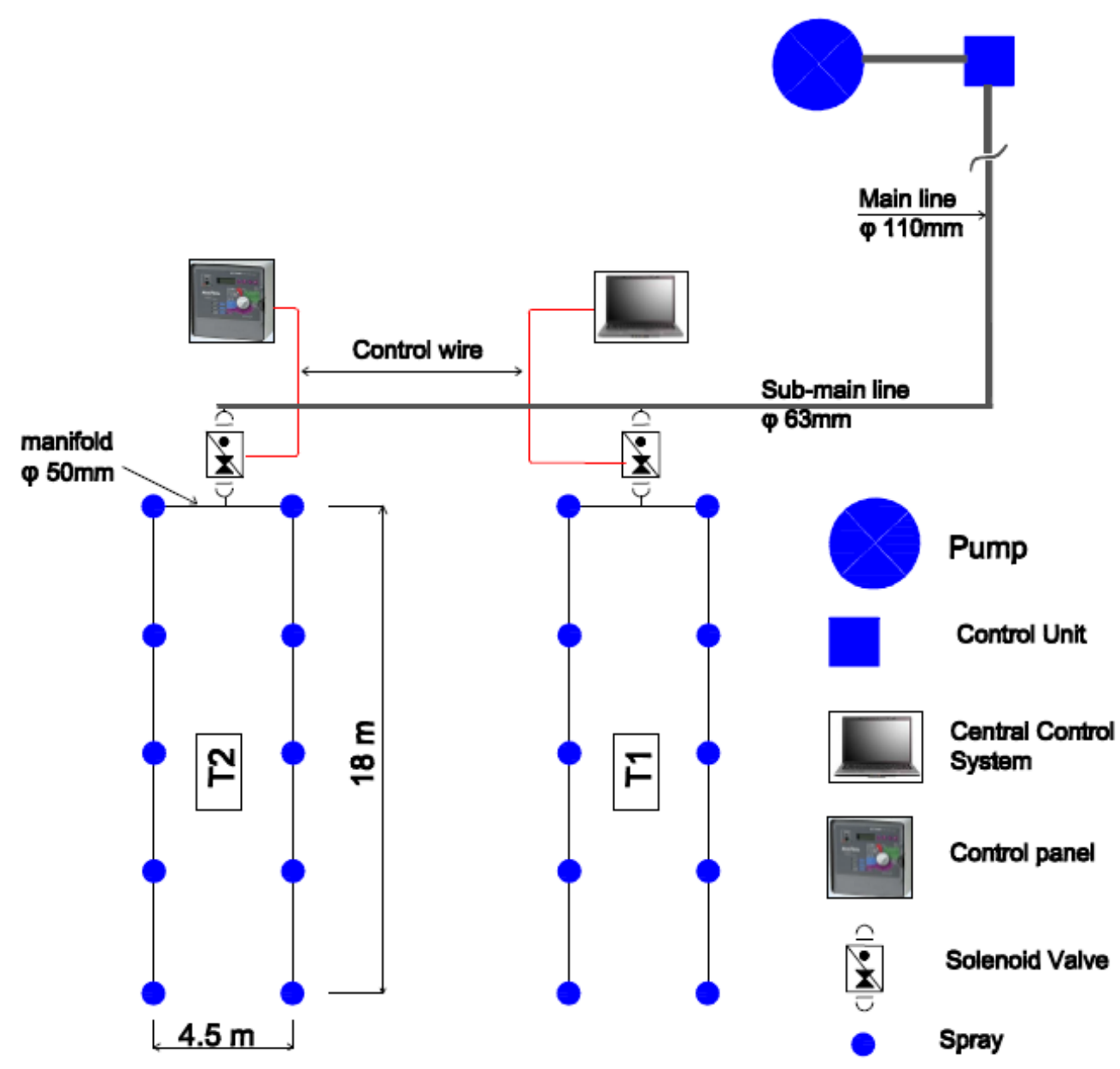

Fig. 1. Experimental Layout. 


\section{3-6- Calculation of landscape water require- ments}

\section{3-6-1- The Landscape Coefficient Method}

The Landscape Coefficient Method was derived specifically to estimate the water loss from landscape plantings Irrigation Association (IA) (2005).

Landscape coefficients (KI) are calculated from three factors: species (ks), density (kd), and microclimate $(\mathrm{kmc})$ :

$$
K L=(k S)(k d)(k m c)
$$

The landscape coefficient factors can be described as follows:

The species coefficient (ks): This factor ranges from 0.1 to 0.9 and is divided from very low to high. The species factor ranges apply regardless of vegetation type (tree, shrub, herbaceous). it is based on water and agricultural crops use studies Irrigation Association (IA), (2009).

The density coefficient (kd): This factor is divided into three categories: low (0.5-0.9), average (1.0) and high (1.1-1.3).

The microclimate coefficient (kmc): This factor ranges from 0.5 to 1.4 and is separated into three categories: low (0.5-0.9), average (1.0) and high (1.1-1.4).

Irrigation Association (IA) (2005), stated that the landscape coefficient method calculations give estimates of the water needs, not exact values, and adjustments to irrigation amounts may be needed.

Can be estimated using the landscape evapotranspiration formula:

$$
E T L=(K L)(E T o)
$$

\section{Where:}

Landscape Evapotranspiration $(E T L)=$ Landscape Coefficient (KL)x Reference Evapotranspiration (ETo).

ETo as a reference to a cool-season grass species with height (from 3 to 6 inc.tall, $7.62--15.24 \mathrm{~cm}$ ). Castello et al (1993)

\section{Estimating the Crop water use (CWU)}

$$
C W U=E T O \times K L
$$

Where:

CWU: Crop water use (in. or $\mathrm{mm} /$ period).

ETo: Reference ET based on cool-season grass (in. or $\mathrm{mm} /$ period).

$\mathrm{KL}$ : Landscape coefficient (dimensionless).

$$
\text { I.R.= EtL/Ea }
$$

Where:

I.R. : The irrigation requirement.

ETL : Landscape Evapotranspiration.

Ea : The irrigation efficiency that could be noted as: $85 \%$ for sprinkler irrigation systems Allen et al (1998).

\section{RESULTS AND DISCUSSION}

\section{4-1- Effect of criteria turf controlling system on irrigation water management}

The data was collected (Jan.-Dec. 2014) show the highest values seasonal crop water use (SCWU) was in summer from June to August under Control unit (C.U) based on operator experience with $\left(620.7 \mathrm{~mm} / \mathrm{m}^{2}\right)$ on other hand under central control system (C.C.S) we use $\left(467.6 \mathrm{~mm} / \mathrm{m}^{2}\right)$. Data collected in spring season based on (C.U) with $\left(419.3 \mathrm{~mm} / \mathrm{m}^{2}\right)$ and under (C.C.S) with (356.1 $\mathrm{mm} / \mathrm{m} 2$ ), spring and summer are two more season for water consumption, because of this result (C.C.S) maximize water use efficiency.

The data was collected (jan-dec2015)show the highest values seasonal crop water use (SCWU) was in summer from June to August under Control unit (C.U) based on operator experience with (713 $\mathrm{mm} / \mathrm{m}^{2}$ ) on other hand under central control system (C.C.S) we use $\left(536.8 \mathrm{~mm} / \mathrm{m}^{2}\right)$. Data collected in spring season based on (C.U) with (460.1 $\mathrm{mm} / \mathrm{m}^{2}$ ) and under (C.C.S) with $\left(396.4 \mathrm{~mm} / \mathrm{m}^{2}\right.$ ), spring and summer are two more season for water consumption, because of this result (C.C.S) maximize water use efficiency. 
Table 4. Seasonal crop water use (SCWU) \& water saving in years of (2014 and 2015)

\begin{tabular}{|c|c|c|c|c|c|c|c|}
\hline \multirow{2}{*}{ Year } & \multirow{2}{*}{ Caiteria } & \multirow{2}{*}{$\begin{array}{c}\text { Controlling } \\
\text { System } \\
\text { type }\end{array}$} & \multicolumn{5}{|c|}{ Climatic growing season } \\
\hline & & & Winter & Spring & Summer & Autumn & Total \\
\hline \multirow{4}{*}{2014} & \multirow{2}{*}{$\begin{array}{c}\text { SCWU } \\
\left(\mathrm{mm} / \mathrm{m}^{2}\right) \\
\text { microclimatic } \\
\text { season }\end{array}$} & C.C.S & 123.4 & 356.1 & 467.6 & 359.6 & 1306.7 \\
\hline & & C.U & 168.1 & 419.3 & 620.7 & 309.6 & 1517.7 \\
\hline & Water saving & C.C.S/C.U & -44.7 & -63.2 & -153.1 & 50.0 & \\
\hline & $\begin{array}{c}\text { Water saving } \\
\text { percentage, } \\
\%\end{array}$ & C.C.S/C.U & 13.90 & 36.21 & 17.74 & 32.75 & \\
\hline \multirow{4}{*}{2015} & \multirow{2}{*}{$\begin{array}{c}\text { SCWU } \\
\left(\mathrm{mm} / \mathrm{m}^{2}\right) \\
\text { microclimatic } \\
\text { season }\end{array}$} & C.C.S & 199.2 & 396.4 & 536.8 & 304.8 & 1437.3 \\
\hline & & C.U & 258.4 & 460.1 & 713.0 & 282.4 & 1713.9 \\
\hline & Water saving & C.C.S/C.U & -59.2 & -63.7 & -176.2 & 22.4 & \\
\hline & $\begin{array}{c}\text { Water saving } \\
\text { percentage, } \\
\%\end{array}$ & C.C.S/C.U & 29.70 & 16.06 & 32.82 & 7.35 & \\
\hline
\end{tabular}

As shown in Figs. 2 and 3 data indicate that the highest values of seasonal crop water use (SCWU) was the in the summer season from June to Aug. under Control unit based on operator experience and the value was higher also in the two years of (2014 and 2015).
Data illustrated in Fig. 4 indicated the water saving by using central control system (C.C.S) based on weather station was about $14 \%, 36 \%$, $18 \%$ and $33 \%$ in Autumn, Winter, spring and summer respectively in season (2014) and 7\%, 29.7\%, $16 \%, 33 \%$ in Autumn, Winter, spring and summer respectively in season (2015).

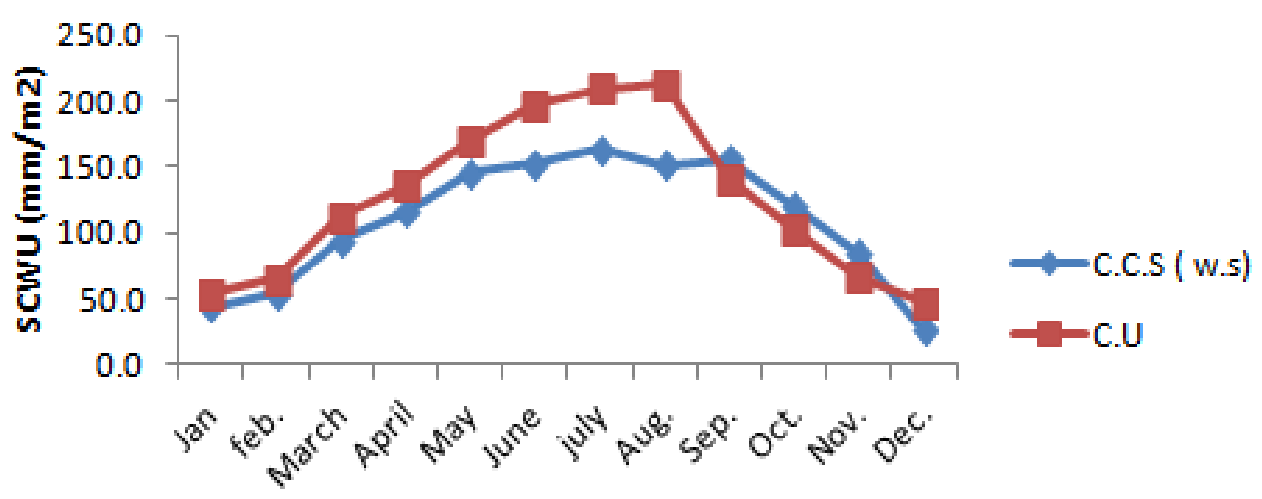

Months of 2014

Fig. 2. Seasonal crop water use (SCWU) in year of 2014 


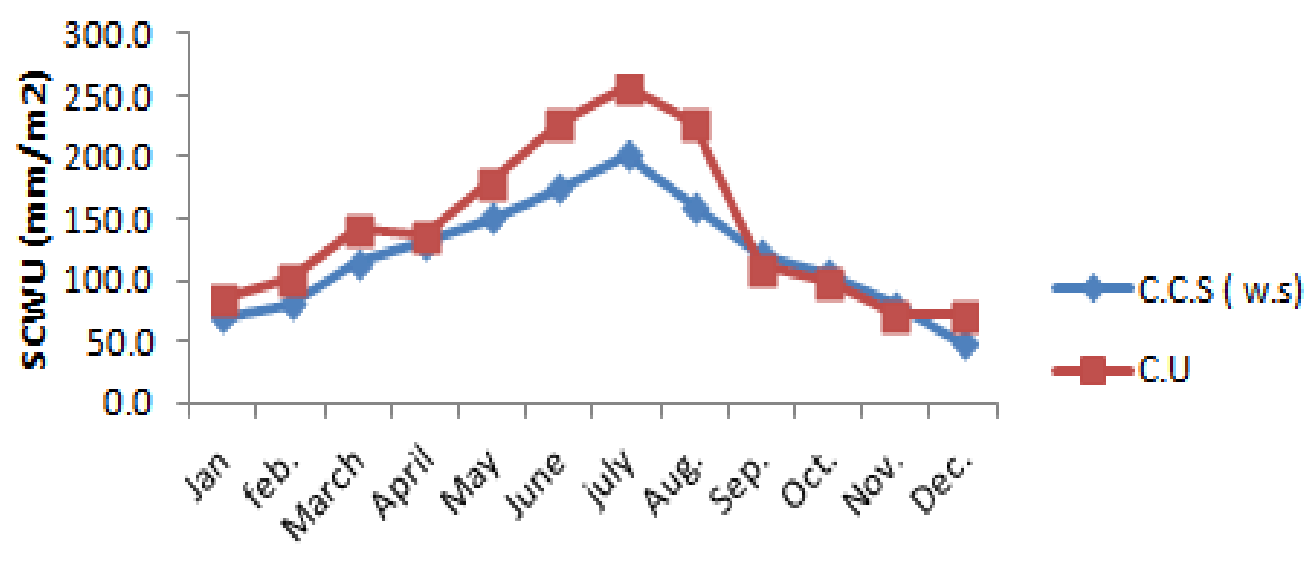

Months of 2015

Fig. 3. Seasonal crop water use (SCWU) in year of 2015

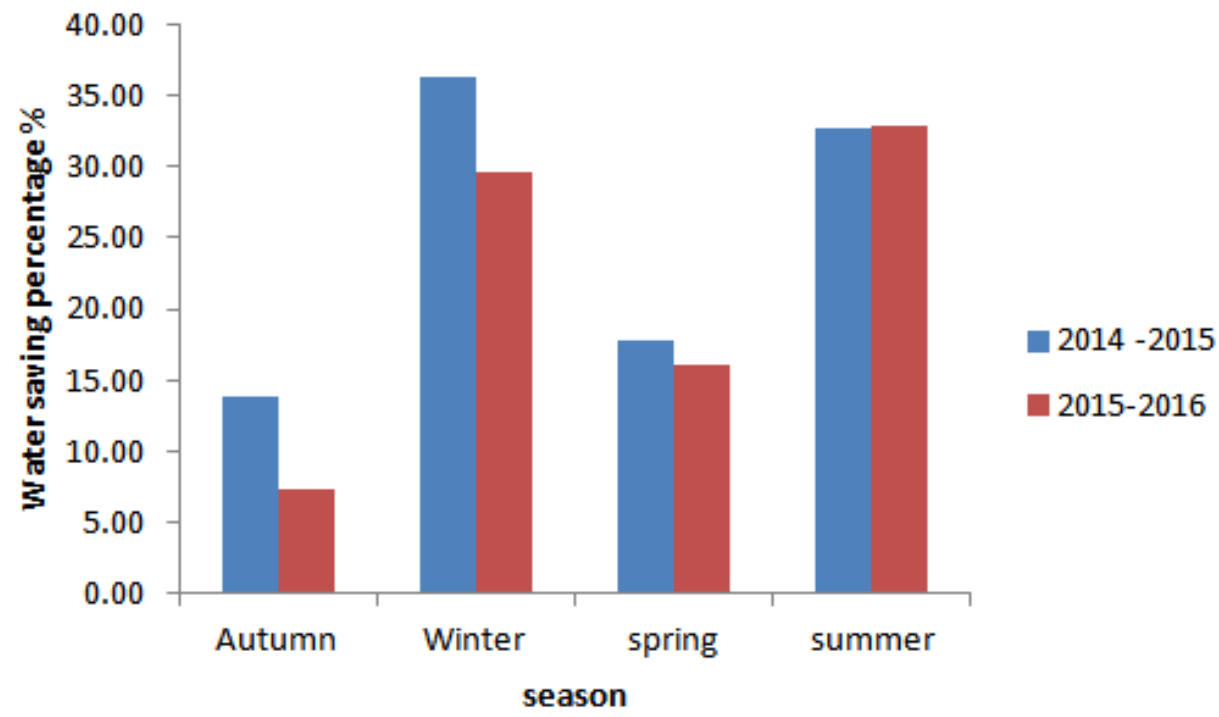

Fig. 4. Water saving percentage years of 2014 and 2015

4-2- Effect of turf controlling system on operating time and energy consumption

Tabulated data in Table 5, which illustrated in Fig. 6 and Fig. 7 indicate that the highest values of power consumption was under Control unit based on operator experience (with about $314 \mathrm{KW}$ ) more than that under central control system (C.C.S) based on weather station in season (2014) and (with about $347 \mathrm{KW}$ ) in season (2015). 
Table 5. Operating time and energy consumption in year (2014) and year (2015)

\begin{tabular}{|c|c|c|c|c|c|c|}
\hline \multirow[t]{2}{*}{ Year } & \multirow[t]{2}{*}{ Criteria } & \multirow{2}{*}{$\begin{array}{l}\text { Controlling } \\
\text { System } \\
\text { type }\end{array}$} & \multicolumn{4}{|c|}{$\begin{array}{l}\text { operating time and energy consumption time } \\
\text { (season) }\end{array}$} \\
\hline & & & Winter & Spring & Summer & Autumn \\
\hline \multirow{4}{*}{2014} & \multirow{4}{*}{$\begin{array}{c}\text { Operating } \\
\text { time (min) } \\
\text { Power } \\
\text { consumption } \\
\text { (KW/season) }\end{array}$} & C.C.S & 949 & 351 & 945 & 603 \\
\hline & & C.U & 1035 & 445 & 1255 & 740 \\
\hline & & C.C.S & 474 & 175 & 472 & 302 \\
\hline & & C.U & 518 & 223 & 628 & 370 \\
\hline \multirow{4}{*}{2015} & \multirow{4}{*}{$\begin{array}{c}\text { Operating } \\
\text { time (min) } \\
\text { Power } \\
\text { consumption } \\
\text { (KW/season) }\end{array}$} & C.C.S & 1024 & 391 & 890 & 673 \\
\hline & & C.U & 1125 & 486 & 1228 & 832 \\
\hline & & C.C.S & 512 & 196 & 445 & 336 \\
\hline & & C.U & 563 & 243 & 614 & 416 \\
\hline
\end{tabular}

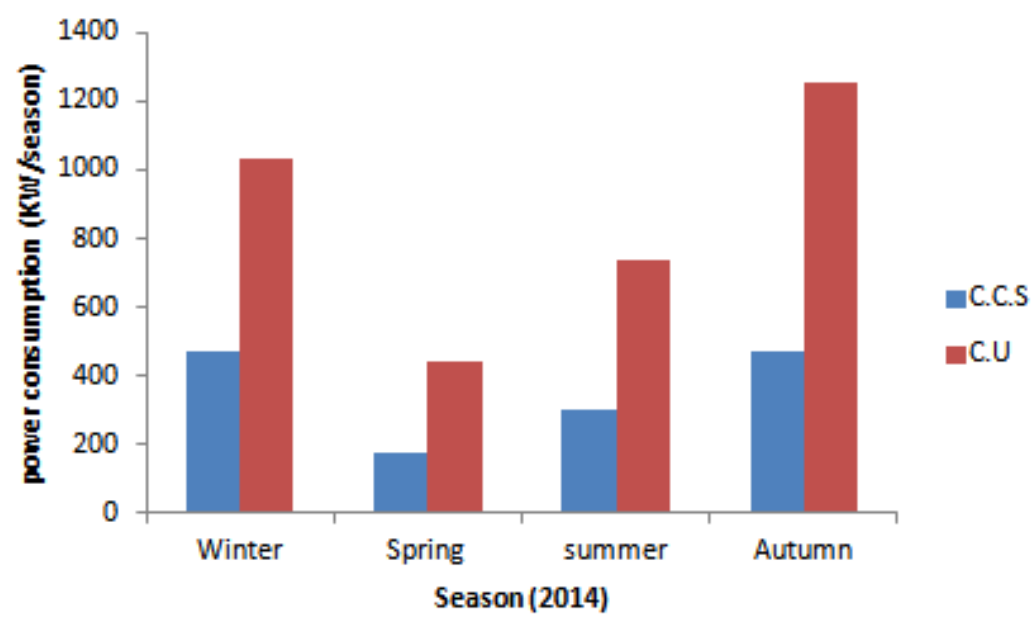

Fig. 6. Power consumption in year of 2014

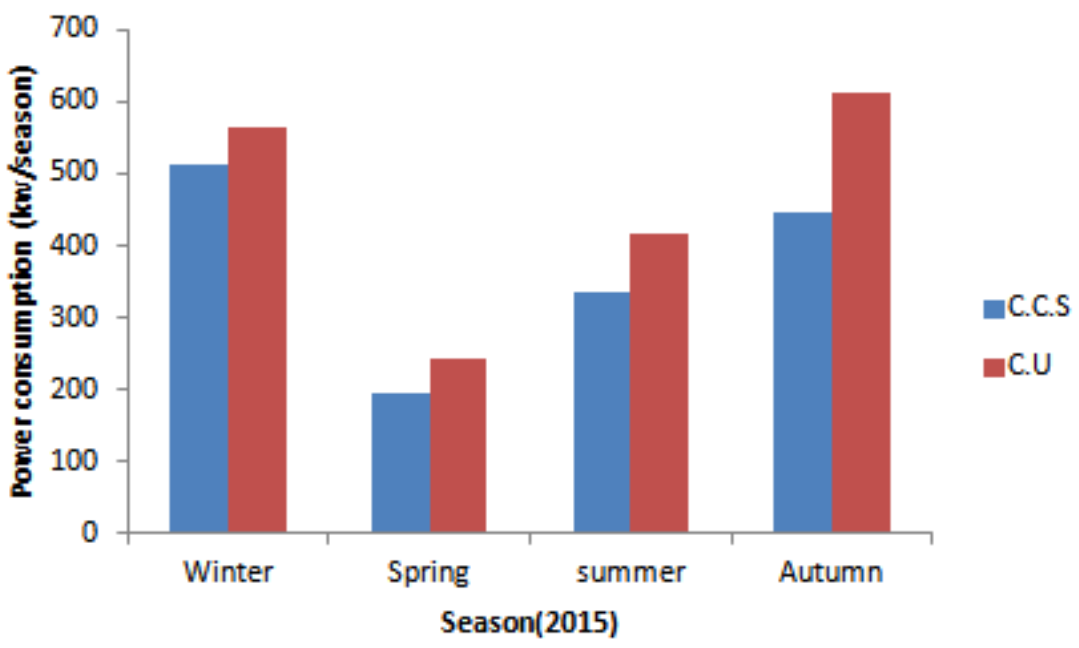

Fig. 7. Power consumption in year of 2015 


\section{4-3- Cost of landscape irrigation system based on recent techniques}

Tabulated data in Table 6 indicate that the results revealed that the cost of water consumption for the central control system based on the data of the meteorological station for the two years 2014 and 2015, the years of study were 106810 L.E./ 2 years compared with the other irrigation schedule when calculated according to the operator's experience was 131010 L.E./ 2years. Where the cost of 36172, 13603, 23393 and 33642 L.E./ 2years in the winter, spring, summer, autumn and respectively of the central control system and 39600, 17068, 28820 and 45522 L.E./ 2years in the winter, spring, summer, autumn respectively of the other system.

Table 6. Cost of water consumption in years of (2014) and (2015)

\begin{tabular}{|c|c|c|c|c|c|}
\hline \multirow{2}{*}{ Criteria } & $\begin{array}{c}\text { Controlling } \\
\text { System } \\
\text { type }\end{array}$ & Winter & Spring & Summer & Autumn \\
\cline { 3 - 6 } & c.c.s & 36172 & 13603 & 23393 & 33642 \\
\hline $\begin{array}{l}\text { cost of water } \\
\text { consumption } \\
\text { L.E./ 2years }\end{array}$ & c.u & 39600 & 17068 & 28820 & 45522 \\
\hline
\end{tabular}

\section{CONCLUSIONS}

Data analysis and out findings could be summarized as follows:

- It has been proven that the schedule for irrigation based on daily weather station data using a central control system (C.C.S).(w.s) maximize the irrigation water use efficiency and enhance the irrigation water saving more than the traditional ways of scheduling, that based on calculated according to the operator experience by about $14 \%$, $36 \%, 18 \%$ and $33 \%$ in Autumn, Winter, spring and summer respectively in season (2014) and 7\%, $29.7 \%, 16 \%$, 33\% in Autumn, Winter, spring and summer respectively in season (2015).

- The results revealed that scheduling practices based on weather station data by using central control system could reduce the average of power consumption (about $314 \mathrm{KW}$ ) in season (2014) and (about $347 \mathrm{KW}$ ) in season (2015).

- That the results revealed that the cost of water consumption for the central control system based on the data of the meteorological station for the two years 2014 and 2015, the years of study were 106810 L.E./ 2years compared with the other irrigation schedule when calculated according to the operator's experience was 131010 L.E./ 2 years.

\section{REFERENCE}

Allen, R.G., Pereira, L.S., Raes, D. and Smith, M. 1998. Crop evapotranspiration: Guidelines for computing crop water requirements - FAO Irrigation and Drainage, FAO, Rome, 56 p.

Bharat, R.S. 2006. Crop water requirements and water productivity. Concepts and practices. College of Agric. Engineering. Punjab Agric. Univ., Ludhiana, pp. 125-128.

Castello, L.R., Matheny, N.P. and Clark, J.R. 1993. Estimating water requirements of Landscape plantings, the landscape coefficient method, Crop. Ext., U.C. Division of Agric. and Natural Resources, Leaflet, 21, 49-53.

Dabach, S, Lazarovitch, N., Šimůnek, J. and Shani, U. 2013. Numerical investigation of irrigation scheduling based on soil water status. Irrig. Sci., 31, 27-36.

David A. Shaw and Dennis R.P. 2009. Landscape irrigation system evaluation and management. San Diego County, CA, UC Cooperative Extension. pp. 1-49.

Davis, S.L. and Dukes, M.D. 2016. Importance of ET controller program settings on water conservation potential. Applied Eng. Agric., 2, 251-262. 
De Silva, C.S., Weatherhead, E.B., Knox, J.W. and Rodriguez-Diaz, J.A. 2007. Predicting the impacts of climate change. A case study of paddy irrigation water requirements in Sri Lanka. Agric. Water Manag 93, 19-29.

Irrigation Association (IA), 2005. Landscape irrigation scheduling and water management, $22 \mathrm{p}$.

Irrigation Association (IA), 2009. WaterSense Commercial and Institutional Sector Comments, 2 p.

Mccready, M., Dukes, M. and Miller, G. 2009. Water conservation potential of smart irrigation controllers on St Augustine grass. Agric. Water Manage., 96, 1623-1632.

Naeem, M. and Rai, N.A. 2005. Determination of water requirements and response of wheat to irrigation at different soil moisture depletion levels. Int. J. Agric. Biol., 07-5, 812-815.

Pereira, L.S., Oweis, T. and Zairi, A. 2002. Irrigation management under water scarcity. Agric. Water Manag 57, 175-206.

Sebei, A., Chabani, F., Suissi, F. and Abdelljaoued, S. 2004. Hydrologie et qualité des eaux de la nappe de Grombalia (Tunisie NordOriental). Revue Sécheresse 15(2), 159-166. 


\section{إدارة الرى اعتمادا على التقتيات العديثة}

نبيله عباس محمد - عبد الغنى محمد الجندى - خالد فران الباجورى - اسامه محمد بدير قسم الهندسه الزراعيه - كليه الزراعه - جامعه عين شمس - صندوق بريد 68 حدائق شبرا 11241- القاهره - مصر

والثتاء والربيع والصيف على التوالي في الموسم

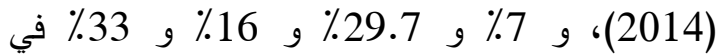
الخريف والثتاء والربيع والصيف ولى على التوالي في

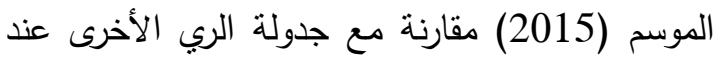
احتسابها وفقاً للطريقة التقليدية. وبالإضافة إلى إلى ذلى ذلك اللك

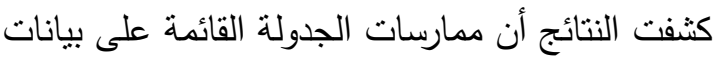

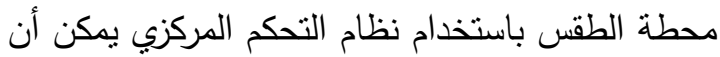

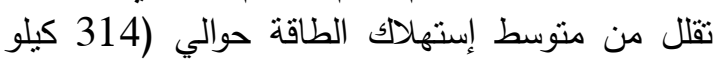
واط) في الموسم (2014) وحوالي (347 كيلو واط) في الموسم (2015).

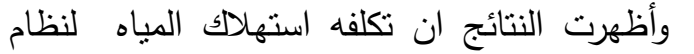
التحكم المركزي اعنمادا على بيانات محطه الارصاد النياد لمده سنتين 2014 و2015 وهم سنوات الدراسه كانت 106810 جنيه مصري مقارنة مع جدولة الري الأخرى النداني عند احتسابها وفقا لخبره المشغل التى كانت 131010

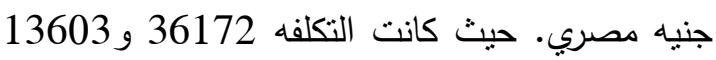

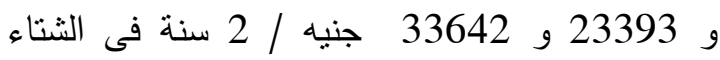
والربيع و الصيف والخريف على التوالى لنظام التحكم

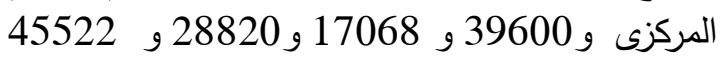
جنيه / 2 سنة فى الثناء والربيع و الصيف والخريف و ولفي

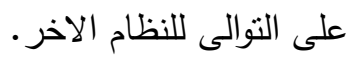

الكلمات الدالة: جدولة الري، التحكم المركزي، محطة الطقس، المناظر الطبيعية الطية الطية

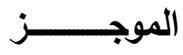

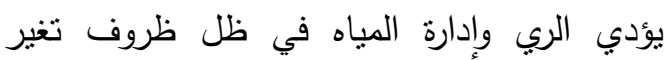

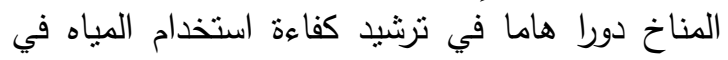
عمليات التتمية الزراعية ،خاصة في ظل فئل ظروف النظم البيئيه القاحلة. لذلك كان الهدف من هذه الدراسة تقدير منطلبات مياه الري لمناطق المناظر الطبيعية المدخرية

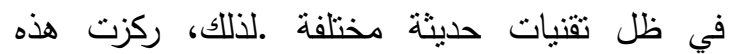

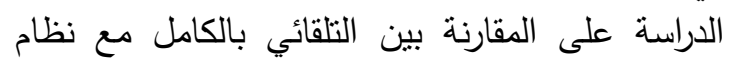

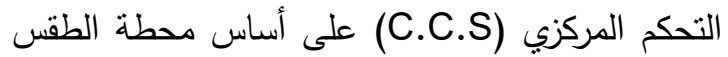

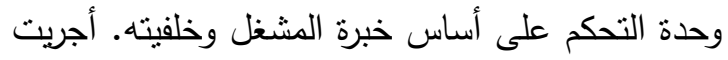
التجارب خلال عامين (من يناير 2014 إلى دئ ديسمبر المبر 2015)، في الموقع الذي يقع في المنطقة 5، القاهرة

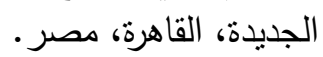
وأظهرت النتائج جدولة الري اعنمادا علي بيانات

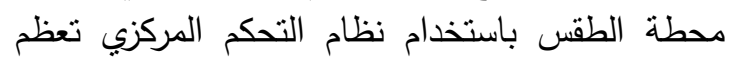
من كفاءة استخدام مياه الري وزيادة كمية توفير مياه

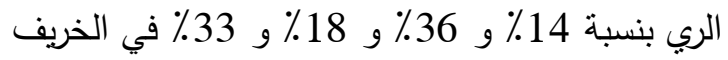



1955

مجلة اتحاد الجامعات العربية

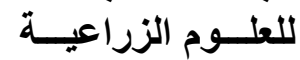

جامعة عين شمس الزعل ، القاهرة

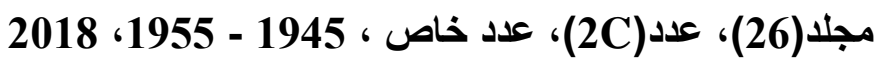

تحكيم: ا.د ياسر عزت عرفه

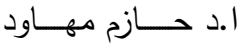

